ADAM KOZAK (Instytut Historii im. Tadeusza Manteuffla PAN, Poznań) https://orcid.org/0000-0002-7601-5298

\title{
O metodzie badań nad małżeństwem późnośredniowiecznym
}

[Magdalena B i n i a ś - S z k o p e k, Małżonkowie przed sądem biskupiego oficjała poznańskiego w pierwszej ćwierci XV wieku, (Publikacje Instytutu Historii UAM, t. 179), Instytut Historii UAM, Poznań 2018, ss. 294.]

Prezentowana publikacja, będąca podstawą uzyskania przez Autorkę habilitacji, wpisuje się w popularny w nauce światowej, ale jeszcze słabo reprezentowany w Polsce, nurt badań nad małżeństwem w późnym średniowieczu i wiążącymi się z tą instytucją sporami prawnymi rozstrzyganymi przede wszystkim przez sądy kościelne ${ }^{1}$. Magdalena Biniaś-Szkopek za najważniejsze cele swojej książki przyjęła „przedstawienie materiału źródłowego - - związanego z problemami małżonków z diecezji poznańskiej w XV wieku”, „wybór i przeprowadzenie statystyk dla znalezionych w księgach not dotyczących omawianej kwestii”, co miało z kolei posłużyć „odtworzeniu obrazu problemów nękających wskazane małżeństwa w omawianym miejscu i czasie”, wreszcie „omówienie funkcjonowania konsystorza poznańskiego, wymienienie rodzajów rozpatrywanych w nim procesów, zakresu jego władzy oraz stosowanego systemu kancelaryjnego" (z Wprowadzenia na s. 7-26, tu s. 13). W toku kwerend archiwalnych w najstarszych księgach konsystorza poznańskiego serii acta causarum (Archiwum Archidiecezjalne w Poznaniu, Konsystorz Generalny w Poznaniu, sygn. AC 1-9) Autorce udało się odnaleźć znaczną liczbę „,550 indywidualnych procesów małżeńskich dla okresu 1404-1426" (s. 17), przy czym uściślić należy, że względnie kompletny materiał $\mathrm{z}$ akt oficjalskich zachował się jedynie dla okresu 1404-1410, 1419-1421 i 1423-1426, a z lat 1411, 1417, 1418 i 1422 pochodzą tylko pojedyncze wpisy.

Praca podzielona jest na trzy części. W pierwszej (Małżeństwo w dokumentach kościelnych a praktyka sądów konsystorskich w średniowieczu, s. 27-93), mającej charakter wprowadzenia do właściwego tematu, w dwóch rozdziałach omówione zostały skrótowo normy późnośredniowiecznego prawa kanonicznego (powszechnego

${ }^{1}$ Przykładowo Ch. D o n a h u e Jr., Law, Marriage, and Society in the Later Middle Ages. Arguments About Marriage in Five Courts, Cambridge 2007, gdzie najszerzej zebrana dalsza literatura przedmiotu. Zamiar zajęcia się zagadnieniem tzw. spraw małżeńskich sygnalizowała niegdyś również przedwcześnie zmarła Izabela $\mathrm{S}$ k i e r s k a, zob. jej, Rozwiązanie małżeństwa w Polsce późnego średniowiecza w świetle praktyki sądów kościelnych, w: Manželství v pozdním středověku: rituály a obyčeje, Praha 2014 (Colloquia mediaevalia Pragensia 14), s. 35 , przyp. 1. 
i partykularnego) odnoszące się do instytucji małżeństwa oraz organizacja sądownictwa kościelnego w Polsce i diecezji poznańskiej (na s. 61-70 pobieżna informacja o zachowanych księgach konsystorskich). Znalazło się tu też miejsce na przedstawienie procesujących się w konsystorzu poznańskim stron (podrozdział: Małżonkowie przed obliczem oficjała poznańskiego, czyli kto sądził się w sądzie konsystorskim, s. 83-91). Fragment ten jednak rozczarowuje, ponieważ nie znajdujemy tu przedstawienia właściwości osobowej i terytorialnej sądu czy szerszych informacji o przynależności stanowej podsądnych, bądź o ich statusie majątkowym, lecz tylko pobieżne podliczenia odnotowanych zawodów spierających się oraz analizę imiennictwa (co nie ma bezpośredniego znaczenia dla badanego tematu). Dopiero po tym Autorka przechodzi już do właściwego omówienia procesów małżeńskich.

Część II (Wokół obietnicy małżeńskiej, s. 95-159) niemalże w całości poświęcona jest procesom mającym na celu ustalenie, czy spierające się strony w ogóle były małżonkami. Stanowiły one aż 60\% (330 procesów) zebranych na potrzeby książki spraw. Główną przyczyną tych trudności była oczywiście powszechna wówczas praktyka zawierania małżeństwa w formie świeckiej (bez zapowiedzi w kościele parafialnym i bez obecności kapłana, a często także bez uroczystej ceremonii i bez świadków). Na pierwszy rzut oka za niezręczność należałoby natomiast uznać omówienie w tym miejscu (i to w książce o tytule „Małżonkowie...”) 56 spraw dotyczących zhańbienia, gwałtu i pozbawienia dziewictwa (podrozdział o tytule nieumiejętnie łączącym łacinę i język polski: Zadośćuczynienie za stupro i defloratio zamiast małżeństwa, s. 134-142). Argumentem za włączeniem tych wszystkich sporów był zapewne fakt, że w części przypadków (38 skarg) mężczyzna miał skłaniać kobietę do współżycia obietnicą przyszłego małżeństwa (znane wyroki nakazywały jednak winowajcy co najwyżej wypłatę odszkodowania).

W części III (W kręgu małżeńskich przeszkód, s. 161-241) M. Biniaś-Szkopek omawia sprawy o stwierdzenie nieważności małżeństwa, kolejno ze względu na bigamię (Autorka zakwalifikowała tu 164 spory, związane przeważnie z długotrwałym oddaleniem się bez wieści poprzedniego małżonka, bądź trudnością z ustaleniem, czy wcześniejszy związek zawarty został w sposób ważny), niemoc płciową (28 przypadków zawsze dotyczących impotencji) ${ }^{2}$, przymus (21 skarg), a także pokrewieństwo i powinowactwo (11 procesów); nie odnotowano natomiast powoływania się przez strony na inne przeszkody. Do analizy, ponownie nieco sztucznie, dołączono rozdział o konfliktach w ważnie zawartych małżeństwach (Bez szans na stwierdzenie nieważności małżeństwa czyli oprawcy i cudzołożnicy, s. 223-241 - rzecz niewątpliwie winna być rozpatrywana w odrębnej części). Całość pracy wieńczy Zakończenie (s. 243-249), gdzie próżno jednak szukać odniesienia do celów pracy czy przełomowych wniosków. Ważne wydaje się jednak ukazanie powszechności faktu zawierania małżeństw w formie świeckiej i skali problemów wynikających z braku rejestracji ślubów, a więc m.in. niepewności co do - używając anachronizmu - ,stanu cywilnego", trudności rozróżnienia małżeństwa i konkubinatu czy stosunkowo często

2 Jest to nieco rozszerzona wersja artykułu Autorki, Małżeńska przeszkoda impotencji i oziębłości płciowej w świetle akt poznańskiego konsystorza z XV wieku, Kwartalnik Historyczny 126,2019 , nr 2, s. 253-281. 
występującej formalnej bigamii. Dalej umieszczono obszerną bibliografię (s. 251269), skorowidz osób (s. 271-283, ułożony według imion, można jednak zastanowić się, czy ktoś z czytających będzie za jego pomocą szukać anonimowych Jakuba z Piekar czy Katarzynę z Poznania) oraz indeks nazw geograficznych (s. 285-288); ten ostatni jest niezwykle przydatny dla badań regionalistycznych, ale pomija miejscowości niezidentyfikowane przez Autorkę w tekście głównym, np. wsie Orle Małe (obecnie Orliczko) i Orle Maiori (Orle Wielkie), wspomniane na s. 197 i 198. Praca posiada również streszczenie angielskie (s. 289-293).

Nie ulega wątpliwości, że prezentowana książka jest pracą ważną, stanowi bowiem pierwszą w krajowej historiografii próbę monograficznego omówienia konfliktów małżeńskich rozstrzyganych w masowej skali w XV w. przez sądy kościelne. Co szczególnie ważne, wykracza ona od strony źródłowej poza kanon, który od ponad 100 lat stanowią Acta capitulorum nec non iudiciorum ecclesiasticorum selecta, wydane przez Bolesława Ulanowskiego (Kraków 1894-1908), i wprowadza do obiegu naukowego nowy materiał w postaci zapisów aż 550 procesów z poznańskich akt konsystorskich ${ }^{3}$. Podkreślić trzeba przy tym duży trud, jakim musiało być łączenie rozproszonych po księgach zapisek w dokumentację konkretnej sprawy. Niejako przy okazji Autorka pokazuje na przykładzie konfliktu Grzegorza i Mirochy z Rogoźna, jak zwodnicze może być korzystanie z selektów. B. Ulanowski wydał bowiem (t. II, nr 979) jedynie zapiskę z 22 X 1424 r., z której wynikało, że przedmiotem wątpliwości był fakt dobrowolnego złożenia przez Mirochę przysięgi małżeńskiej (kobieta twierdziła, że choć była bita przez matkę, to nie wyraziła zgody na ślub). Tymczasem kwerenda M. Biniaś-Szkopek ujawniła dalszych kilkanaście wpisów dotyczących tego sporu oraz nowe okoliczności - Grzegorz borykał się jednocześnie z zarzutami Świętoszy z Rogoźna, która podawała się za jego prawowitą żonę (s. 208-209; Autorka omyłkowo pisze, że sprawa toczyła się w 1426 r.).

Wobec pracy M. Biniaś-Szkopek wysunąć można też garść uwag krytycznych, a w niektórych miejscach zachęca ona do polemiki czy podjęcia dyskusji metodycznej. Choć Autorka w zasadzie bardzo dobrze orientuje się w anglojęzycznej literaturze przedmiotu, to zauważyć można tu brak znajomości monografii Richarda H. Helmholza poświęconej procesom małżeńskim (ważna jest tu prawnicza perspektywa oraz skupienie się na procedurach sądowych, w tym na postępowaniu dowodowym $)^{4}$, prac Sary M. Butler (podejmują one m.in. tematy przemocy w rodzinie oraz „rozwiązania" małżeństwa) $)^{5}$ czy dysertacji Marthy A. Brozyny o piętnastowiecznych procesach małżeńskich w konsystorzu gnieźnieńskim, która mogłaby dawać świetny materiał porównawczy ${ }^{6}$ W książce praktycznie brak też odwołań do literatury

${ }^{3}$ Na rękopiśmiennym materiale zapiskowym z krakowskich i lubelskich ksiąg konsystorskich z powodzeniem oparła się ostatnio M. K oł a c z - C h m i e l, Mulier honesta et laboriosa. Kobieta w rodzinie chłopskiej późnośredniowiecznej Małopolski, Lublin 2018.

${ }^{4}$ R.H. He $1 \mathrm{~m} \mathrm{~h}$ o $\mathrm{z}$, Marriage Litigation in Medieval England, Cambridge 1974.

5 S.M. B ut l e r, Runaway Wives: Husband Desertion in Medieval England, Journal of Social History 40, 2006, nr 2, s. 337-359; t a ż, The Language of Abuse: Marital Violence in Later Medieval England, Leiden-Boston 2007; t a ż, Divorce in Medieval England. From One to Two Persons in Law, New York 2013.

${ }^{6}$ M.A. B r o z y n a, Private Oaths, Broken Promises, and Illicit Relations: Marriage Litigation in the Consistory Court of Fifteenth Century Gniezno, Poland, University of Southern 
czeskiej $^{7}$, a także niemieckiej ${ }^{8}$. Ubolewać można tu zwłaszcza nad niewykorzystaniem wzorcowej monografii Christiny Deutsch ${ }^{9}$, gdzie w pierwszej kolejności wiele miejsca poświęcono organizacji sądów kościelnych oraz stosowanej przez nie procedurze (innymi słowy - sposobom dochodzenia do rozstrzygnięcia). Dopiero na tym tle Ch. Deutsch zajęła się drobiazgowym omówieniem procesów w sprawach małżeńskich w szerokiej perspektywie czasowej (znaleźć tu można nie tylko prostą klasyfikację sporów, ale też statystyczną analizę). Całość udokumentowana jest tu schematycznymi regestami zarejestrowanych postępowań sądowych (ujęte są w nich: strony, treść skargi, wyrok sądu, czas trwania procesu oraz dane o sędzim i świadkach) ${ }^{10}$. Nie ulega wątpliwości, że znajomość tych prac mogłaby być cennym punktem odniesienia dla Autorki oraz stanowić inspirację przy konstruowaniu formularza badawczego i wyboru sposobu dokumentowania pracy.

Narracja książki M. Biniaś-Szkopek opiera się głównie na streszczaniu obszerniejszych zapisek ilustrujących dany typ spraw (Autorka nie posługuje się w zasadzie cytatem ze źródła). Porównanie wybranych regestów z materiałem rękopiśmiennym ujawnia jednak zdarzające się Autorce niedokładności czy nawet przeinaczenia. Przykładowo na s. 116 przeczytać można, że „przykładem [spraw o zerwanie zaręczyn - A.K.] może być niedoszłe małżeństwo - - Małgorzaty Menszyny [czyli Mężyny - A.K.], wdowy po zmarłym Mikołaju Menszu [Mężu - A.K.], mieszczaninie z Poznania oraz Marcina, kuśnierza pochodzącego z Riesenburga w Prusach [Prabuty, nieuwzględnione w indeksie - A.K.], zamieszkałego także w Poznaniu. Ona zeznała, że zawarła z nim sponsalia de futuro, a następnie wystąpiła, żeby ich obu od tej przysięgi uwolnić". Tymczasem wedle oryginalnej zapiski Marcin i Małgorzata działali zgodnie - wspólnie oświadczyli, że choć zaręczyli się, to teraz wzajemnie uwalniają się od udzielonej sobie obietnicy ${ }^{11}$. Na s. 128, w rozdziale poświęconym

California 2005 - niepublikowana dysertacja doktorska, dostępna w otwartym repozytorium $<$ http://digitallibrary.usc.edu/cdm/ref/collection/p15799coll16/id/395308>. Por. s. 66-67 recenzowanej pracy, gdzie ubolewanie na „brak - - pełnego wachlarza badań szczegółowych nad dłuższymi okresami działań konsystorzy [w Polsce - A.K.]”.

7 Z. H le dík ová, Zápisy z manželských sporů - nepovšimnutý pramen 15 . století, w: Pocta Josefu Petráňovi. Sborník prací z českých dějin k 60. narozeninám prof. dr. Josefa Petráně, Praha 1991, s. 79-93; B. K o p i č k o v á, Manželské spory žen pozdního středověku v protokolech ústředních církevních úřadů v Praze, w: Žena v dějinách Prahy, Praha 1996, s. 57-65; M. N o d 1, In facie ecclesiae, w: Manželství (jak w przyp. 1), s. 53-61.

${ }^{8}$ Ch. S c h w a b, Das Augsburger Offizialatsregister (1348-1352). Ein Dokument geistlicher Diözesangerichtsbarkeit. Edition und Untersuchung, Köln-Weimar-Wien 2001 (Forschungen zur kirchlichen Rechtsgeschichte und zum Kirchenrecht 25), s. 668-777 (analiza spraw małżeńskich); R. W e i g a n d, Die Rechtsprechung des Regensburger Gerichts in Ehesachen unter besonderer Berücksichtigung der bedingten Eheschließung nach Gerichtsbüchern aus dem Ende des 15. Jahrhunderts, w: tegoż, Liebe und Ehe im Mittelalter, Goldbach 1998 s. 245*-306*; t e n ż e, Zur mittelalterlichen kirchlichen Ehegerichtsbarkeit. Rechtsvergleichende Untersuchung, Zeitschrift der Savigny-Stiftung für Rechtsgeschichte, Kanonistische Abteilung 67, 1981, s. 213-247; P. Er d ö, Eheprozesse im mittelalterlichen Ungarn, tamże 72, 1986, s. 250-276.

${ }_{9}$ Ch. D e u t s c h, Ehegerichtsbarkeit im Bistum Regensburg (1480-1538), Köln-Weimar-Wien 2005 (Forschungen zur kirchlichen Rechtsgeschichte und zum Kirchenrecht 29).

10 Tamże, s. 423-656.

${ }_{11}$ Poznań, Archiwum Archidiecezjalne, AC 9, k. 134 (1426): In causa Martini pellificis de opido Resinburg de Prussia in Poznania morantis cum Margaretha Menchinne relicta olim 
skargom o ustalenie istnienia/nieistnienia małżeństwa, Autorka opisuje rozprawę z 4 VII 1425 r.: „Wojciech z Sadów złożył wniosek przeciw swej żonie Małgorzacie pochodzącej z Poznania o zmuszenie do pozostania z nim w związku. Mężczyzna zeznał, że dali sobie wzajemnie obietnicę małżeńską w obliczu Kościoła w samej katedrze poznańskiej, co ona przyznała. Jednak następnie oświadczyła, że nie chce się wraz z nim przenieść do Sadów. - - Sąd pod karą ekskomuniki nakazał im pozostać małżeństwem". W pierwszej kolejności należy tu wskazać, że sprawa ta została błędnie sklasyfikowana (co wynika nawet z tego streszczenia), dotyczy bowiem skłonienia małżonka do wspólnego zamieszkania (fakt zawarcia małżeństwa nie jest kwestionowany). Dalej należy zauważyć, że to kobieta pochodziła z Sadów, których nie chciała opuścić, ze względu na posiadane tam dobra. Wreszcie trzeba uzupełnić, że oficjał nakazujący Małgorzacie podążyć za mężem, groził jej również karą karceru ${ }^{12}$. Dalej przytoczyć można przykład sprawy Agnieszki z Otorowa (s. 207): „kobieta złożyła petycję, że istnieją przeszkody do zawarcia jej małżeństwa z Wachem. Mężczyzna zeznał, że w obecnym roku dali sobie wiarę małżeńską, na co Agnieszka zaznaczyła, że do podania przyszłemu mężowi ręki zmuszona została siłą". Z zapiski można dowiedzieć się jednak, że to Wach czynił Agnieszce przeszkody w zawarciu nowego małżeństwa, twierdził bowiem, że tuż przed Zapustami ślubowali sobie nawzajem. Kobieta uważała jednak swoją przysięgę za nieważną, ponieważ miała działać pod przymusem $^{13}$. Z kolei na s. 212 przeczytać można, że „,W sobotę 15 kwietnia 1424 roku przed oficjałem stanęli Dominik syn Alberta z Kobylników [recte: Wojciecha z Kobylnik - A.K.] oraz Sinocha [Synocha? - A.K.] z matką swą Stachną z Obornik. Kobiety poprosiły, żeby je zwolnić od żądań mężczyzny, ten jednak odpowiedział, że zawarł z dziewczyną małżeństwo w obliczu Kościoła, a następnie mieszkali ze sobą w jednym domu, zanim ona odeszła - - Sędzia - - nakazał jej wrócić do Dominika, natomiast matce pod groźbą kar kościelnych zabronił namawiać córkę do odejścia od niego". W tym przypadku właściwy wpis konsystorski inaczej przedstawia początek sporu - kobiety zwróciły się do sądu o zdjęcie ciążących na nich „ekskomuniki, agrawacji i reagrawacji", które nałożono na wniosek Dominika. Dopiero wtedy mężczyzna wyjaśnił, że pierwotną przyczyną sporu było odejście jego żony Synochy

Nicolai Mench civis Poznaniensis, sponte venientes confessi sunt, quia sponsalia de futuro -contraxerunt --, tamen Martinus prefatam Margaretham a promissione predicta liberam fecit et dimittit et similiter Margaretha ipsum Martinum sponte liberum a premissis fecit et dimittit.

12 Tamże, AC 8, k. 169: In causa Alberti cum Margaretha muliere de Sadi uxore sua, Albertus - - petivit Marga(retham) compelli, ut ei adhere(re)t, ut marito suo, cui est post festum Pasce proximum preteritum in facie ecclesie in ecclesia kathedrali Poznaniensi copulata. Ex adverso mulier confessa est matrimonium contractum cum Alberto et quod sibi est in facie ecclesie copulata, sed dixit, quod nollet eum sequi de Sadi, quia ibi habet bona etc. Dominus vero mandavit dicte Margarethe, ut Alberto marito suo adhereret sub penis censure ecclesiastice et carceris.

${ }_{13}$ Tamże, AC 6, k. 64v (1423): In causa Agnetis ancille de Ottorowo cum Wach laico de ibidem, prefata Agnes verbo proposuit, quomodo ipse Wach sibi in contrahendo matrimonio impedimentum prestat. Ex adverso dictus Wach dixit, quod sibi ante Carnisbrevium [!] de anno presenti fidem suam dedit ac secum per verba matrimonium faciencia contraxit, dicens ipse Wach: Vis Agnes tu me? Qua respondit: Volo. Ipsa Agnes ex adverso respondit nunquam fuit voluntas sua, sed per vim fuit tracta et manus sua eidem Wach data. 
i jej powrót do matki ${ }^{14}$. Zauważyć można ponadto, że sprawa ta nietrafnie omawiana jest w kontekście przeszkód małżeńskich, główną osią konfliktu jest bowiem nie stwierdzenie nieważności małżeństwa, lecz przywrócenie wspólnego pożycia. Jak widać, choć w żadnym z przytoczonych przykładów nie doszło do całkowitego przeinaczenia okoliczności sprawy, to jednak dokładność streszczeń Autorki i poprawność kwalifikowania sporów do poszczególnych kategorii pozostawia wiele do życzenia. Weryfikacja wszystkich wpisów jest jednak oczywiście niemożliwa. Być może pewnym wyjściem byłoby tu dokumentowanie trudniejszych czy wątpliwych fragmentów możliwie obszernymi cytatami źródłowymi, co ułatwiałoby kontrolę wywodu.

Choć M. Biniaś-Szkopek nie wspomina o tym wyraźnie we wstępie (por. s. 16-17, 67-70), to analizowana przez nią dokumentacja konsystorska zachowała się tylko fragmentarycznie (nie tylko w aspekcie czasowym, ale też treściowym). Do czasów współczesnych dotrwały jedynie księgi z serii acta causarum $^{15}$, gdzie notowano wyłącznie informacje o sesjach sądowych i czynnościach procesowych stron, nie uwzględniano natomiast zeznań świadków oraz - z zasady - ostatecznych rozstrzygnięć sędziego. Wyjątek stanowiły postępowania toczone w tzw. procedurze sumarycznej - stosowanej m.in. w niektórych sprawach małżeńskich (decyzja należała tu do powoda/powódki), która charakteryzowała się uproszczeniem formalizmów; proces toczył się wtedy m.in. w dużej mierze ustnie, co zmuszało niekiedy pisarzy do wpisywania na bieżąco do protokołu brzmienia wyroków ${ }^{16}$. Niestety Autorka nie zajmuje się bliżej tymi sprawami (kwestia procedur została zamarkowana na s. 83), nie podaje też, dla jakiego procenta z 550 analizowanych spraw zna końcowe rozstrzygnięcia. Jest to o tyle istotne, że w pracy jak mantra powtarzają się stwierdzenia „niestety nic nie wiadomo o decyzjach oficjała” czy ,niestety nie znamy wyroku” itp. (s. 116, 118-120, 127, 132, 133, 139, 140, 142, 168, 169-172, 173, 175, 177, 180, 187, 206, 207, 209, 210, 212, 219, 231). Można też przeczytać (s. 146), że „dziś trudno dociec jednoznacznej przyczyny konkretnych decyzji sędziego, gdyż nie dotrwały z tego okresu zapisy zeznań świadków, które były kluczowe dla wyroku". Powoduje to, że Autorka koncentruje się na referowaniu swoimi słowami twierdzeń

${ }_{14}$ Tamże AC 7, k. 75v: In causa matrimoniali Dominici filii Alberti de Cobilniki cum Sinocha filia Stachne de Oborniki, mulier cum filia - - pecierunt se absolvi a sentenciis excommunicacionis, aggravacionis et reaggravacionis, quibus ad instanciam dicti Dominici ligate fuerant. Ex adverso Dominicus dixit eas non esse absolvendas ex eo, quia cum ea matrimonium contraxit et illud in facie ecclesie per copulam consumavit - - et in domo Dominici eidem Dominico commansit, nunc vero vagatur ab eodem et per matrem tenetur et fovetur. Sinocha vero confessa est, quia matrimonium cum Dominico contraxit--. Dominus M(athias) officialis - - mandavit eidem Sinosche, ut ad Dominicum maritum predictum rediret sibique commaneret, affectu coniugali ipsum pertractando - - et dicte Stachne inhibuit, ne filia contra voluntatem Dominici teneret et foveret sub censuris ecclesiasticis.

15 Dla ścisłości odnotować należy też jedną księgę z serii Constitutiones procuratorum z lat 1421-1426 (Co. Pr. 1), która została jednak utworzona wtórnie ze składek wyjętych z innych ksiąg przez dwudziestowiecznych archiwistów.

16 Por. uwagi R.H. H e $1 \mathrm{~m}$ h o $1 \mathrm{z}$ a, Marriage Litigation, s. 112-140, oraz Ch. D e u t s c h, Ehegerichtsbarkeit, s. 177-261. O procesie sumarycznym zob. też K. P e n n in g t o n, Introduction to the Courts, w: The History of Courts and Procedure in Medieval Canon Law, Washington 2016, s. 24-29. 
stron oraz na próbach ich typologizacji, nie potrafi zaś przeważnie ocenić, jak do skarg odnosili się współcześni sędziowie. Co za tym idzie, M. Biniaś-Szkopek nie pokazuje ani ,„prawa w działaniu”, ani stosunku ówczesnych do kwestii dobrowolności zgody na małżeństwo czy przemocy w rodzinie. Autorka wpędziła się w sygnalizowane problemy źródłowe niejako na własne życzenie, w zespole akt konsystorza poznańskiego zachowały się bowiem średniowieczne księgi wyroków oraz zeznań świadków (komplet trzech serii istnieje dla lat 1473-1478 i 1491-1497) ${ }^{17}$. W moim przekonaniu praca uwzględniająca możliwie najpełniejszy wachlarz akt sądowych różnych serii byłaby lepiej uzasadniona metodycznie, dawałaby bowiem kompletniejszy i wielostronny (perspektywa świadków) obraz instytucji małżeństwa i toczących się wokół niej sporów oraz pozwalałaby na zastosowanie bardziej rozbudowanego formularza badawczego.

Brak zainteresowania Autorki dla procedur sądowych ma jeszcze dalsze skutki. $\mathrm{Na}$ s. 155-156 w podsumowaniu rozdziału poświęconego procesom o ustalenie istnienia małżeństwa przeczytać można: „,w tych sprawach powodowie powoływali się na cały szereg okoliczności, które towarzyszyły momentowi składania przysięgi od cytowania wypowiedzianych słów, przez podanie rąk, wymianę wianków, pierścieni, towarzyszenie świadków, podanie i miejsca i czasu, wspólne zamieszkanie, podjęcie współżycia, spłodzenie potomstwa oraz ostatecznie ogłoszenie zapowiedzi w parafii i potwierdzenie obietnic w obliczu Kościoła. - - Analiza materiału z poznańskiego konsystorza wskazuje na fakt, iż żaden z argumentów, z wyjątkiem faktu potwierdzenia małżeństwa w obliczu Kościoła, nie dawał pewności co do decyzji oficjała i wyroku, który zapadał". Tymczasem można postawić tezę (trudną do udowodnienia bez drobiazgowej reanalizy źródeł, które zresztą przeważnie nie są konkretnie wskazywane), że decydujące dla losów danej skargi było nie powołanie się na konkretną okoliczność towarzyszącą zawieraniu (rzekomego) małżeństwa, lecz znacznie bardziej banalna możliwość dowiedzenia tych faktów w sądzie według reguł przyjętych w procesie rzymsko-kanonicznym ${ }^{18}$. Nie są zatem uprawnione rozważania, czy oficjałowie bardziej „,preferowali” małżeństwa potwierdzone wymianą wianków, nad te, gdzie nupturienci podawali sobie na znak zgody ręce, skoro o rozstrzygnięciu decydowała i tak możliwość przedstawienia sądowi świadków tego zdarzenia. Na tym tle nie może dziwić, że ślub zawarty w kościele wobec kapłana i osób postronnych, poprzedzony publicznymi zapowiedziami, zwyczajnie było łatwiej udowodnić. Należy również zwrócić uwagę na fragment (s. 231): „możemy natomiast mówić o pewnej regule w postępowaniu sędziego, który w przypadku tego typu spraw [oskarżeń o cudzołóstwo - A.K.] nie decydował się na pełne stwierdzenie nieważności małżeństwa, a jedynie formę pośrednią, separację - - . W ani jednym ze znalezionych 11 przypadków nie przeprowadzono pełnego stwierdzenia nieważności związku, w niektórych jedynie sędzia posunął się do ogłoszenia separacji”. Passus

${ }^{17}$ A. K o z a k, W poszukiwaniu metody edycji późnośredniowiecznych kościelnych źródeł sądowych, w: Editiones sine fine, t. I, Toruń 2017, s. 173-175.

18 O postępowaniu dowodowym zob. W. L i t e w s k i, Der römisch-kanonische Zivilprozeß nach den älteren ordines iudiciarii, Kraków 1999, s. 353-445 (tu na s. 410-411 m.in. o tym, że aby uznać twierdzenie za udowodnione, wymagano co do zasady zgodnego zeznania dwóch świadków). 
ten zaskakuje o tyle, że zaledwie akapit wcześniej (s. 230-231) Autorka referowała prace kanonistów (Stefan Biskupski, Ginter Dzierżon), którzy w oparciu o normy z Liber extra wskazywali, kiedy w przypadku wykazania zdrady współmałżonka można było orzec separację od łoża i stołu ${ }^{19}$. Przywołać w tym miejscu można znaną paremię ignorantia iuris nocet, przy czym w tym przypadku szkodę ponosi badacz dochodzący do nietrafnych wniosków w oparciu o błędne rozumienie norm prawnych czy też brak wiedzy o regułach procesowych. Na marginesie tych wywodów można też odnotować, że w omawianej pracy nieliczne są bezpośrednie odniesienia do przepisów powszechnego, a w szczególności partykularnego prawa kanonicznego, co mogłoby się wydawać użyteczne w analizie akt sądowych (zestawianie „prawa w księgach” z ,prawem w działaniu”).

Warto też poruszyć sposób prowadzenia narracji. W Zakończeniu (s. 245) sama Autorka deklaruje: „Pomimo że stanęliśmy wobec źródła o charakterze masowym, przyjęta w pracy metoda nie została oparta wyłącznie na statystyce, choć część przeprowadzonych analiz można zaliczyć do nurtu badań kwantytatywnych". Stwierdzenie to sformułowane zostało na wyrost. Po pierwsze liczba tabel i wykresów w pracy nie jest znaczna (s. 84, 85-86, 87-88 i 89-91 [frekwencja imion], s. 112, 113, 136, 137 [zestawienie czytelnie porządkujące dane z procesów o zhańbienie], 167 i 168 [informacje o bigamii], 186 [liczba spraw małżeńskich i zarzutów impotencji w poszczególnych księgach], 191-198 [stabelaryzowane streszczenia spraw o impotencję]). Po drugie Autorka ogranicza się tu właściwie do rachowania liczby spraw danego typu (czasami w układzie rocznym) i wskazywania, jaki procent całości one stanowią. Tymczasem wartościowy wzorzec stanowi tu dobrze znane M. Biniaś-Szkopek opracowanie Charlesa Donahue $\mathrm{Jr}^{20}{ }^{20}$, gdzie autor obliczał chociażby zmiany udziału danej kategorii spraw w czasie (w dwóch kolejnych stuleciach), procentowy rozkład typów argumentacji stron, odsetek spraw zakończonych rozstrzygnięciem sądu czy współczynnik sukcesu przy poszczególnych rodzajach skarg (także z podziałem na płeć powoda $)^{21}$. Na tym tle pomysł na badanie ograniczające się do kategoryzowania spraw (zresztą nie zawsze trafnego) i streszczania lakonicznych not sądowych (trudno na podstawie kilkuwierszowych wpisów, gdzie nieznane są zeznania ewentualnych świadków i rozstrzygnięcia, przeprowadzić wartościowe „,case study”) prezentuje się dość skromnie. Choć książka M. Biniaś-Szkopek jest wciągającą lekturą - jak każdy zbiór smakowitych anegdot z życia prywatnego minionych pokoleń - to jej ustalenia nie wykraczają poza wskazanie powszechności jednego typu spraw

19 Być może oczekiwanie Autorki, że w przypadku cudzołóstwa możliwe było stwierdzenie nieważności małżeństwa, wzięło się z pomieszania adulterium - czyli naruszenia zasad pożycia w prawowitym związku - z przeszkodą występku, która w dawnym brzmieniu stanowiła, że nie jest możliwe zawarcie ważnego małżeństwa z osobą, z którą utrzymywało się kontakty seksualne jeszcze za życia poprzedniego małżonka (regulacja ta miała zniechęcać w domyśle do zabójstwa obecnego męża lub żony w celu stworzenia nowego oficjalnego związku).

${ }^{20}$ M. B in i ás - S z k o p e k, Źródła waśni i konfliktów małżeńskich w Europie przed soborem trydenckim (wokół książki Charlesa Donahue, Law, Marriage, and Society in the Later Middle Ages: Arguments about Marriage in Five Courts, Cambridge 2007), Historia Slavorum Occidentis 2017, nr 4 (15), s. 101-114.

${ }^{21}$ Por. Ch. D o n a h u e Jr., Law, s. VIII-X (List of Tables), 63-89 (Statistics: The Court of York, 1300-1500), 225-235 (Counting Marriage Cases in the Court of Ely). 
(niepewność co do istnienia małżeństwa, bigamia) i incydentalności innych (stwierdzenie nieważności małżeństwa na podstawie przeszkody pokrewieństwa; pojedyncza sprawa o rozwiązanie zaręczyn).

Na zakończenie, niejako z obowiązku, przychodzi wskazać drobne usterki redakcyjno-korektorskie, np. na s. 57 znajdziemy nieprawidłowy mianownik auctoritate ordinaria, a na s. 77 wyrażenie in consistorii. Łacina nie zna takich słów jak nobila i familiara (oba na s. 84), scolar (s. 85, 179), contract (s. 120) czy tractat (s. 171). Na s. 88 i 153 do tekstu w języku polskim wkradły się słowa z ortografią łacińską („Thomisława”, „pana Ramscha”). „Adwokat z Kazimierza” (s. 211) to oczywiście wójt z Kaźmierza (dawne miasto, obecnie wieś pod Szamotułami), zaś łacińskie słowo amici tłumaczyć należałoby w naszym kontekście jako „krewni”, a nie jako „przyjaciele” czy „posłańcy” (tak na s. 116 i 118).

Prezentowana publikacja budzi mieszane uczucia. Podkreślić należy po raz kolejny pracowitą kwerendę oraz wykorzystanie, po raz pierwszy w takiej skali od lat, nowego materiału źródłowego. Z drugiej strony dyskusyjne wydaje się być sięgnięcie po akta z pierwszej ćwierci XV wieku, podczas gdy księgi późniejsze, z lat 70. i 90. tegoż stulecia, umożliwiłyby dokładniejsze i bardziej wieloaspektowe prześledzenie problemu. Podkreślić należy przy tym, że dla poprawnej analizy sporów sądowych warunkiem niezbędne jest rozumienie działania sądu i operowanie możliwie kompletnym materiałem źródłowym, który ukazuje cały proces, a nie tylko jego przypadkowe fragmenty. Dodatkowo wątpliwości budzą nieścisłości zauważone przy streszczaniu niektórych zapisek. Ostatecznie wypada zgodzić się z M. Biniaś-Szkopek, która w podsumowaniu swojej książki (s. 248) podkreśla potrzebę kontynuowania badań nad tematem przy wykorzystaniu dalszych archiwaliów. 